back the heat rays from entering the eye. The atmosphere of the mills, unfortunately, is very dusty and the men perspire freely. To prevent the collection of moisture and dust on the goggles it would be necessary to treat the glass with some preparation similar to that used on the gas masks in France. This, of course, should not be sticky or greasy. I am making a few practical experiments with one of these preparations at present. The framework should be light with plenty of air space between frame and face, and not metallic, as a metal frame gets very hot and gives rise to the popular opinion among the men that goggles draw the heat to the eye. There is another difficulty in the use of goggles: the workers themselves object to wearing them, but I have seen a few old men in the tinplate mills wearing glasses after cataract extraction which were both heavy and devoid of any anti-moisture collecting preparation. Much, I think, could be done to overcome the men's prejudice by suitable propaganda. In the tinplate mills I do not think it is possible to suggest any other reasonable form of prevention.

\title{
BIBI_IOGRAPHY
}

Legge, T. M.-Report on Cataract in Glassworkers, included in second report of the Departmental Committee on Compensation for Industrial Diseases.

Robinson, W.--"Bottlefinishers' Cataract," Brit. Med. Jl., January 24, 1903. "Bottlemakers' Cataract," Brit. Med. Jl., August 17, 1907.

Burge., W. E.-Abstract bulletin of the Nela Research Laboratory, paper 61, "The Injurious Effects of Ultra-violet Rays on Living Tissue," Brit. Ji. Ophthal., May, 1920.

Hartridge and Hill.- "The Transmission of Infra-red Rays by the media of the Eye, and the transmission of Radiant Energy by Crookes' and other glasses," Proc. Royal Soc., B. Vol. LXXXIX, 1915.

Fuchs. - "Text-book of Ophthalmology," translated by A. Duane, 1918.

\section{A SERIES OF CASES OF “ GLASSBLOWERS' CATARACT" OCCURRING IN CHAINMAKERS} BY

\author{
B. H. St. Clair Roberts, \\ DUDLEY.
}

DURING the last few years I have collected notes of about twentyfive cases of cataract in men and women engaged in chainmaking, all of whom presented in one eye or both a posterior polar and cortical opacity of a type closely resembling that described as occurring in glassblowers.

The centre of the chain trade in this country is located at Cradley Heath and the surrounding Black Country. The district is some square miles in extent, and there are several thousands of people engaged in the trade.

Chain is made by hand, the work being a specialized type of 
blacksmithing. A few chainmaking machines have been introduced into the district, but have not proved successful, so that chain manufacture is likely to remain a skilled craft.

A piece of rolled iron rod, cut to a suitable length, is heated and bent into the shape of a link, the two ends in apposition are heated to a white heat and welded together to complete the link by being hammered on an anvil.

The workers wear no kind of protection and gaze during the whole of the working day either into the fire to judge when the ends of the link are hot enough to weld, or at the white-hot metal whilst hammering it on the anvil.

Large chain is made in factories in which only men are engaged. The hearths are about three feet six inches in height and about five feet apart, and are arranged in rows with an air blast supply pipe to each. Small chain is made chiefly by outworkers; alongside a chainmaker's cottage is a small outhouse smithy, in which often both mother and children are working. The hearths are blown by hand bellows, the children supplying the motive power.

In my series of cases many of those affected were exposed to the glare at a very early age by working in their parent's smithy.

Although chainmaking is largely a family occupation, being handed down from parents to children, there can be no hereditary tendency. First, the appearance of the opacity and its onset in middle life (40 to 55) is different from any type of congenital cataract; and, secondly, no kind of relationship could be traced between any of the cases, and, further, the district is too populous and of too wide extent for there to be any close intermarrying.

I believe that many more are affected than come for treatment, for it is a matter of common belief among the workers that their sight should fail between the ages of 50 and 60 .

The following cases are more or less typical of the series. G. B- is a tall healthy man, aged 45, who gave up work two years previously owing to failing vision. He commenced as a helper at chainmaking at the age of fourteen, and became a masterworker at the age of eighteen and has worked at the same trade ever since.

Outwardly the eyes appear normal except for a greyish haze in the centre of the pupils. On dilating the pupils one sees in the left eye a posterior polar and cortical opacity which appears to be about $3 \mathrm{~mm}$. in diameter; it has a dense whitish rosette-shaped centre with projections into a more translucent peripheral portion. This greyish translucent periphery has a well-defined edge from the remainder of the lens. There is also a tiny but well-defined central opacity in the anterior cortex. The right eye is similar in appearance. Vision $6 / 60$ both. The vitreous and fundi appear normal.

After a preliminary iridectomy in the right eye, the lens became completely opaque in a few months, and was then removed with good 
result. A brother, eight years older, who works as an anchor smith, is unaffected, also two children, aged 14 and 16, are unaffected.

$\mathrm{H}-$, a man, aged 58, has worked at chainmaking for fifty years, he commenced at the age of 7 by working the bellows. The right eye is healthy and vision normal. He has noticed that the left eye has been failing for the past three years.

On dilating the pupil one sees a well-defined circular opacity about $3 \mathrm{~mm}$. in diameter centrally situated in the posterior cortex. The opacity is not uniformly dense for there is a denser centre suggesting in appearance a cell with its nucleus. Away in the periphery of the lens are a number of dot-like opacities which are arranged in a circle concentric with the edge of the lens.

T. B-, aged 52, has worked at chainmaking all his life. Vision has been failing for the past three or four years.

On dilating the pupils one sees in the right eye a well-defined posterior polar and cortical opacity. The opacity is slightly oval in shape and has a denser "herring bone" centre.

There is also a small but well-defined anterior polar and cortical opacity.

In the left eye the posterior cortical opacity is about the same size as the right (about $2 \mathrm{~mm}$. in diameter) but is more circular. It also is denser in the centre than the periphery. There is a very small anterior polar and cortical opacity.

S. $\mathrm{H}-$, aged 42 , has worked at chainmaking all his life. Right vision $6 / 18$ partly. There is a small posterior cortical opacity, but otherwise the lens is clear. Left vision 6/60. The opacity is similar in appearance, but has a slightly larger diameter. No other opacities.

J. P- aged 43, has worked at chainmaking since he commenced work. Has noticed his vision failing for the past two years. Right vision 6/12. Left vision also 6/12.

A small sharply-defined posterior cortical opacity in each lens; otherwise the lenses are quite transparent.

In all the cases in which the fundi could be seen there was nothing abnormal found.

\section{CONTACT-ILLUMINATION IN THE EXAMINATION OF THE CORNEA AND ANTERIOR PART OF THE EYE \\ BY \\ Basil Graves, \\ SENIOR HOUSE SURGEON, ROYAL LONDON OPHTHALMIC HOSPITAL.}

ILLUMINATION, for purposes of examination of the cornea and anterior portion of the interior of the eye, by the ordinary method of oblique focal concentration of distant light has the unavoidable 